\title{
Contribution to the Characterization of Lateritic Soils for the Manufacture of Compressed Stabilized Earth Bricks
}

\author{
Cherif Bishweka1,2, Marcelline Blanche Manjia'2,3, François Ngapgue ${ }^{2,4^{*}}$, \\ Ursula Joyce Merveilles Pettang Nana2,3, Chrispin Pettang ${ }^{2,3}$
}

\author{
${ }^{1}$ Department of Civil Engineering, Faculty of Sciences and Applied Technologies, Free University of the Great Lakes Countries, \\ Congo, North Kivu, Goma \\ ${ }^{2}$ Civil and Mechanical Engineering Laboratory, Research and Postgraduate Training Unit for Engineering and Applications \\ Science, Post Graduate School for Science, Technology and Geosciences, University of Yaoundé I, Yaoundé, Cameroon \\ ${ }^{3}$ Department of Civil Engineering, National Advanced School of Engineering Yaoundé, University of Yaoundé I, \\ Yaoundé, Cameroon \\ ${ }^{4}$ Fotso Victor University Institute of Technology, Bandjoun, University of Dschang, Dschang, Cameroon \\ Email: ^fgapguefcr@gmail.com
}

How to cite this paper: Bishweka, C., Manjia, M.B., Ngapgue, F., Nana, U.J.M.P. and Pettang, C. (2021) Contribution to the Characterization of Lateritic Soils for the Manufacture of Compressed Stabilized Earth Bricks. Open Journal of Civil Engineering, $11,411-426$.

https://doi.org/10.4236/ojce.2021.114024

Received: August 19, 2021

Accepted: December 11, 2021

Published: December 14, 2021

Copyright $\odot 2021$ by author(s) and Scientific Research Publishing Inc. This work is licensed under the Creative Commons Attribution International License (CC BY 4.0).

http://creativecommons.org/licenses/by/4.0/

\begin{abstract}
The aim of this study is to contribute to the mastery of the physical characteristics of lateritic soils in order to improve their use for the manufacture of Compressed Stabilized Earth Bricks (CSEB) in the province of North Kivu in the Democratic Republic of Congo (DRC). The study of the physical characteristics of lateritic soils was carried out. Samples were subjected to experimental identification tests on the physical characteristics (water content, density characteristics, particle size distribution and consistency). The results of the laboratory analysis of soil samples show that the water content varies between $5.4 \%$ and $36.99 \%$. The density of the solid grains has an arithmetic mean of $2.5 \mathrm{~g} / \mathrm{cm}^{3}$. The apparent density varies from 0.83 to $1.35 \mathrm{~g} / \mathrm{cm}^{3}$. As for the dry density, it is in the range of 0.61 to $1.25 \mathrm{~g} / \mathrm{cm}^{3}$. These relatively low densities indicate that the material studied has a significant degree of deformability. From the particle size analysis, it appears that the material studied contains an important fraction of fine particles. According to the consistency study, the soils studied are plastic clay as Ap class according to the Central Laboratory for Roads and Bridges (CLRB) geotechnical classification system. The particle size curves of the studied samples are within the preferential range of good soils for the manufacture of CSEB. The points representing the studied samples are within the preferential plasticity range of good soils for the manufacture of CSEB. From the above parameters, it appears that the studied material is well adapted for the manufacture of the Compressed Stabilized Earth Bricks.
\end{abstract}




\section{Keywords}

Lateritic Soils, Identification Tests, Characterization, Classification, Earth Construction

\section{Introduction}

The threat of global warming is real and the economic crisis is imminent. The so-called modern materials such as concrete and steel are almost inaccessible for a large part of the population, because of their high costs. The populations close to the forests have opted for wood construction, but this cannot be truly qualified as sustainable as long as its anarchic use accentuates deforestation and fire rates. The valorization of local materials in the construction of housing and public buildings is a necessity from a sustainable development perspective. Reducing the use of concrete in low-income countries has environmental and economic advantages [1]-[6]. Researchers have proposed tropical soils as a sustainable resource to be utilised in the construction of housing around the world. Laterite is a typical tropical soil that could fill the gap between a housing deficit and provision of modest housing for the growing populations in Africa [7] [8] [9] [10] [11]. However, the earth material is very little adopted, perhaps due to a lack of knowledge of its properties or ignorance of improved techniques of CSEB manufacturing are causes and inadequate implementation of Compressed Stabilized Earth Bricks in the buildings constructed resulting in a limited life cycle. The constructions in raw earth have a connotation of poor and bad quality habitats but this is indeed due to the ignorance of the thermal and hydrometric properties of this material. In addition, it is currently confirmed that the stabilization of CEB by binders and bitumen improves their mechanical strength and their sensitivity to water [12] [13]. The lateritic soils of North Kivu are used by certain social strata for the manufacture of Compressed and Stabilized Earth Bricks without mastering their physical characteristics, which leads to consequences such as the progressive crumbling of the walls, cracks, the poor performance of the plaster, and the discouragement of the use of the said technology. In addition, the CSEB technique is applied in other localities of North Kivu and elsewhere, but with the use of calcareous sand, river sand, sandy clay and not laterite, hence the study of the characteristics of these materials is important for the manufacture of CSEB. This study focuses on characterization and the classification of some lateritic soils on the basis of samples collected from Bweremana (in DRC) for their probable use in the manufacture of Compressed Stabilized Earth Bricks.

\section{Materials and Methods}

\subsection{Sample Materials}

The experimental studies were carried out on samples of lateritic soils collected 
from Bweremana (Figure 1) in North Kivu (DRC). The purpose of this study is to determine the geological context of the site, to make soundings on the horizontal profile of the long pedological and grooving on the vertical wall and the
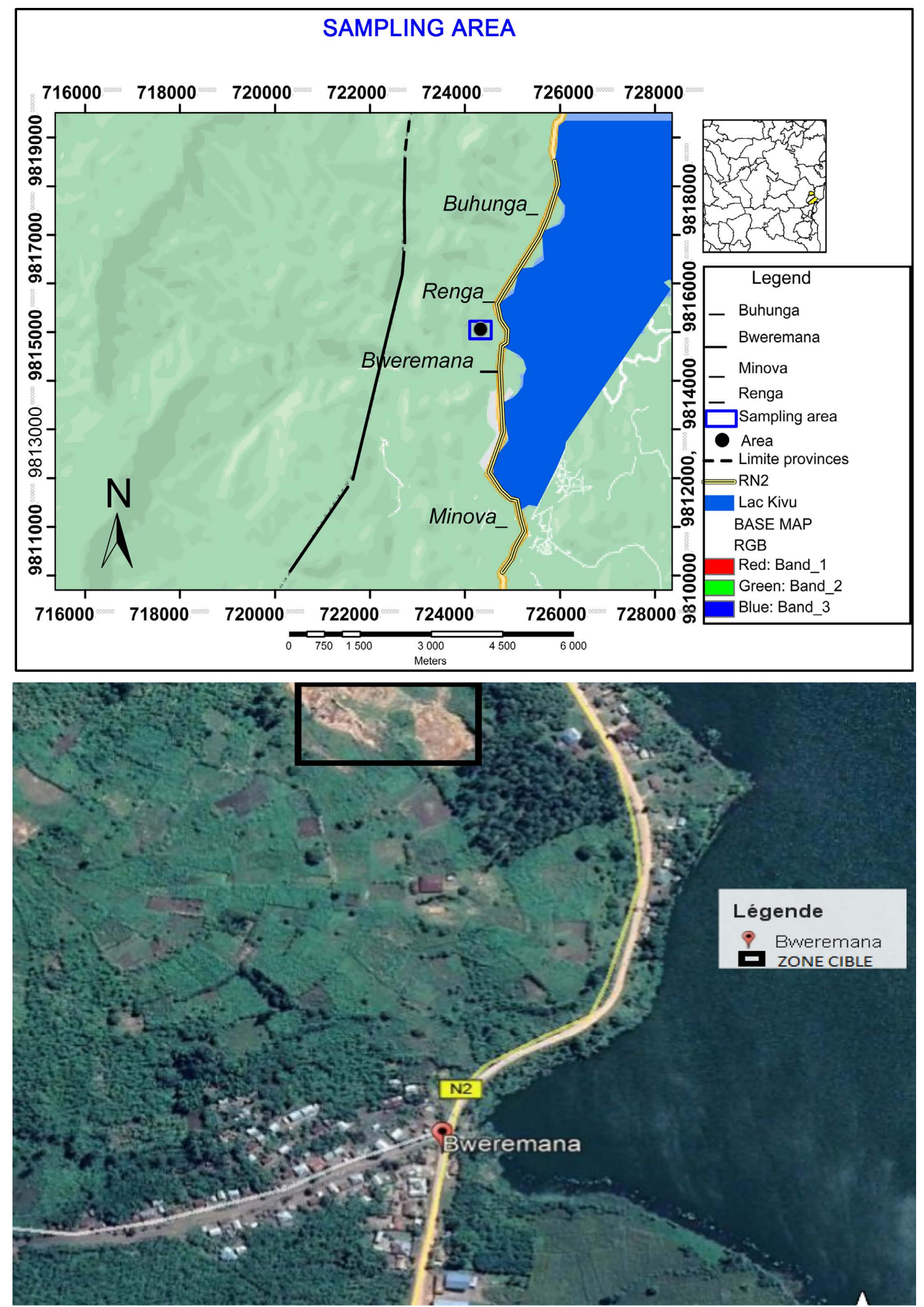

Figure 1. The study area Map. 
main physical characteristics of the samples taken. For this study, soil sampling is done to determine the physical-mechanical properties of the clay soils of the research area. This requires special attention especially since the accuracy and extrapolation of data depends on obtaining samples that retain their characteristic structures in situ [14].

At the pilot site (Figure 2), 12 soil samples were collected to determine the

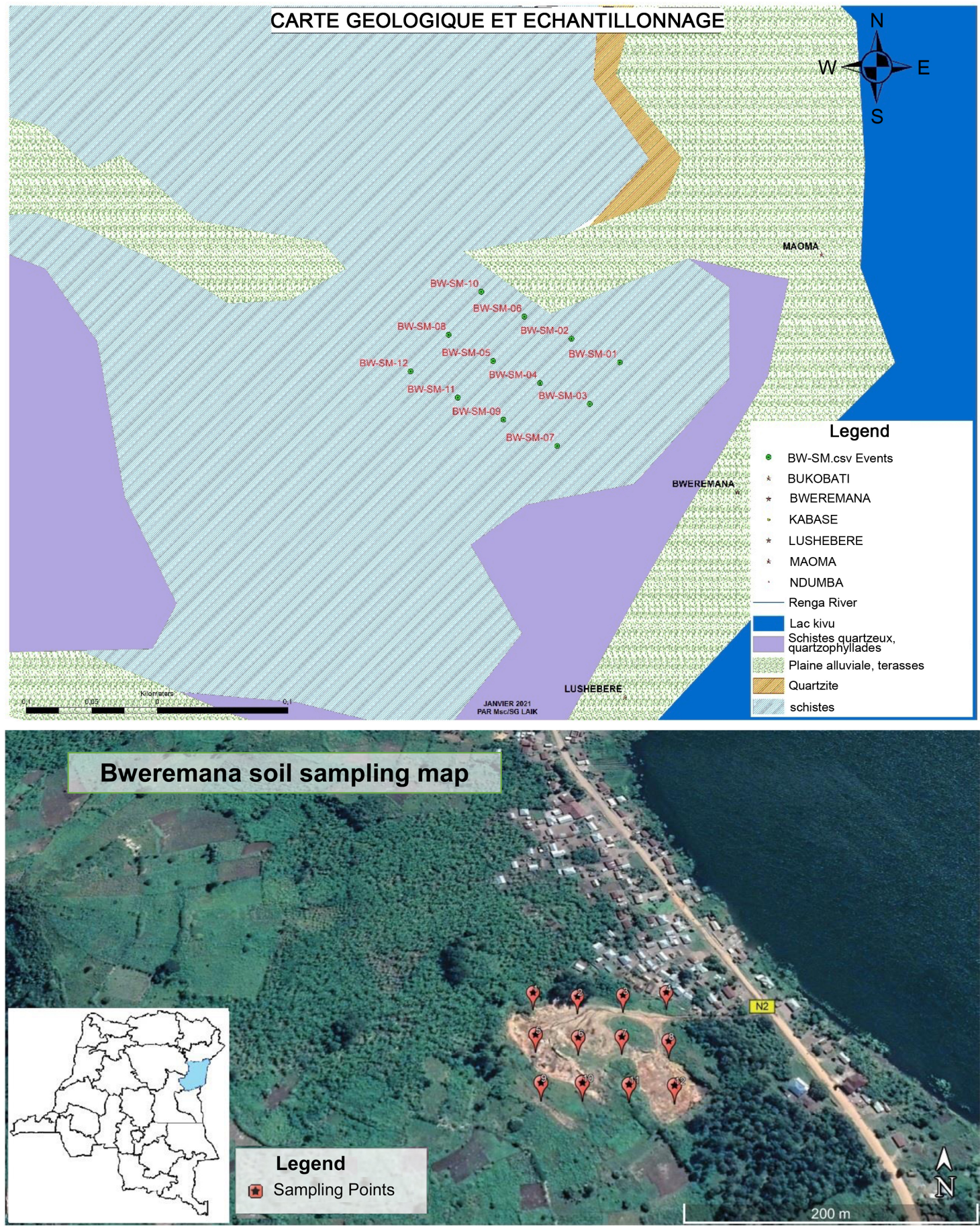

Figure 2. Sampling maps of the study area. 
physical properties of lateritic soils in the study area. Samples for the determination of natural water content and soil density were collected intact by core sampling. Samples for particle size analysis, Atterberg limits and solid grain density were remoulded.

As a result, systematic sampling points with a regular interval of $40 \mathrm{~m} \times 40 \mathrm{~m}$ were adopted in this study. The twelve samples collected were distributed along two N-S oriented lines, equidistant of 40 meters according to the geographical coordinates presented in Table 1.

\subsection{Experimentation Methods}

Some preliminary tests as touch/smell/wash tests gave an apparent classification of the material and its organic content. The bottle test verified the presence of all elements (sand, silt, clay). Cigar and splitting tests allowed us to observe the cohesion of the soil, the proportion and the quality of the clay particles. The study of the physical characteristics of the lateritic soils was carried out on 12 samples collected in Bweremana. The water content of the different samples was determined by the oven drying method, following the experimental standard XP CEN ISO/TS 17892-1, 2005 [15]. The density of the solid grains was determined using the pycnometer, according to the standard NF P 94-054 [16]. The apparent density and the dry density were determined by the cutting kit method according to the NF P 94-053 [17] standard. The wet sieves analysis of the material was carried out by sieving according to the requirements of the NF P 18-560 [18] standard. At the end of the sieving operation, the particles size less than $0.080 \mathrm{~mm}$ were collected. Their particle size analysis was carried out by sedimentometry according to the standard NF P 94-057 [19]. The particle size curves were generated with MATLAB software (Appendix 1 MATLAB code). The study of the

Table 1. Geographic coordinates of the sampling points.

\begin{tabular}{cccc}
\hline Samples & Latitude & Longitude & Altitude \\
\hline BW-SM-01 & 724,435 & $9,814,975$ & 1500 \\
BW-SM-02 & 724,398 & $9,814,993$ & 1490 \\
BW-SM-03 & 724,412 & $9,814,943$ & 1493 \\
BW-SM-04 & 724,374 & $9,814,959$ & 1495 \\
BW-SM-05 & 724,338 & $9,814,976$ & 1489 \\
BW-SM-06 & 724,362 & $9,815,010$ & 1489 \\
BW-SM-07 & 724,387 & $9,814,911$ & 1530 \\
BW-SM-08 & 724,304 & $9,814,996$ & 1491 \\
BW-SM-09 & 724,346 & $9,814,931$ & 1500 \\
BW-SM-10 & 724,329 & $9,815,029$ & 1488 \\
BW-SM-11 & 724,311 & $9,814,948$ & 1489 \\
BW-SM-12 & 724,275 & $9,814,968$ & 1480 \\
\hline
\end{tabular}


consistency of the soils was carried out on the basis of Atterberg limits. The Atterberg limits make it possible to characterize the clayness of a soil, thus determining the remarkable water contents located at the border between the different states (solid, plastic and liquid). The liquidity limit $\left(\mathrm{W}_{\mathrm{L}}\right)$ was determined using the Casagrande apparatus and the plasticity limit $\left(\mathrm{W}_{\mathrm{P}}\right)$ using the roller method, in accordance with standard NF P 94-051 [20]. The plasticity index (PI) was evaluated as the difference between the liquid limit and the plastic limit. Finally a classification of the samples soils was done according to the CLRB geotechnical classification system.

\section{Results and Discussion}

The study of the physical characteristics of lateritic soils was carried out on 12 samples. In this section we present the results of the experimental identification tests on the state of parameters (water content, different densities or density characteristics); particle size composition and consistency parameters.

\subsection{Water Content}

The water content values of samples are presented in Table 2.

Table 2 shows that the water content of samples BW-SM-08 and BW-SM-09 varies between $5 \%$ and 10\%, while samples BW-SM-01, BW-SM-02, BW-SM-04, BW-SM-05, BW-SM-06, BW-SM-07, BW-SM-10 and BW-SM-11 vary between $10 \%$ and $15 \%$. As for the samples BW-SM-03 and BW-SM-12, the values of water content are $37.00 \%$ and $32.60 \%$ respectively. So the water content for all samples varies between $5.40 \%$ and $37.00 \%$ with an arithmetic mean of $14.94 \%$.

\subsection{Density Characteristics}

The density characteristics of the studied soils are presented in Table 3.

Table 3 shows that the solid grain density $\rho$ s has an arithmetic mean of 2.50 $\mathrm{g} / \mathrm{cm}^{3}$. The bulk density $\rho$ ranges from 0.83 to $1.35 \mathrm{~g} / \mathrm{cm}^{3}$, with an arithmetic mean of $1.13 \mathrm{~g} / \mathrm{cm}^{3}$. The dry density $\rho_{\mathrm{d}}$ is in the range of 0.61 to $1.25 \mathrm{~g} / \mathrm{cm}^{3}$ with an arithmetic mean of $1.00 \mathrm{~g} / \mathrm{cm}^{3}$. These densities indicate that the material studied have a non-negligible degree of deformability.

Table 2. Water content of natural materials.

\begin{tabular}{cccc}
\hline Samples & Water content w (\%) & Samples & Water content w (\%) \\
\hline BW-SM-01 & 10.95 & BW-SM-07 & 12.51 \\
BW-SM-02 & 12.28 & BW-SM-08 & 5.40 \\
BW-SM-03 & 36.99 & BW-SM-09 & 6.53 \\
BW-SM-04 & 12.11 & BW-SM-10 & 13.01 \\
BW-SM-05 & 11.27 & BW-SM-11 & 11.20 \\
BW-SM-06 & 14.47 & BW-SM-12 & 32.59 \\
\hline
\end{tabular}




\subsection{Particle Size Distribution}

Completing the wet particle size analysis with the particle size analysis by sedimentometry applied to particles smaller than $0.08 \mathrm{~mm}$ according to the AFNOR (2001) [21] standard, we obtained the particle size curves represented on Figures 3-14. These results show that the largest grain size for all the samples is $2 \mathrm{~mm}$.

In general, the distribution of grains for the different materials is given in $\mathrm{Ta}$ ble 4 .

Table 3. Density characteristics.

\begin{tabular}{cccc}
\hline Samples & $\rho_{\mathrm{s}}\left(\mathrm{g} / \mathrm{cm}^{3}\right)$ & $\rho\left(\mathrm{g} / \mathrm{cm}^{3}\right)$ & $\rho_{\mathrm{d}}\left(\mathrm{g} / \mathrm{cm}^{3}\right)$ \\
\hline BW-SM-01 & 2.50 & 1.30 & 1.17 \\
BW-SM-02 & 2.45 & 1.07 & 0.95 \\
BW-SM-03 & 2.55 & 0.83 & 0.61 \\
BW-SM-04 & 2.50 & 1.04 & 0.93 \\
BW-SM-05 & 2.50 & 1.22 & 1.10 \\
BW-SM-06 & 2.50 & 1.35 & 1.19 \\
BW-SM-07 & 2.50 & 1.11 & 0.99 \\
BW-SM-08 & 2.50 & 1.31 & 1.25 \\
BW-SM-09 & 2.50 & 1.27 & 1.19 \\
BW-SM-10 & 2.50 & 1.03 & 0.91 \\
BW-SM-11 & 2.50 & 1.21 & 1.09 \\
BW-SM-12 & 2.50 & 0.84 & 0.63 \\
\hline
\end{tabular}

Table 4. Grains size distribution of materials.

\begin{tabular}{cccc}
\hline Samples & Coarse sand (\%) & Sand (\%) & Fine sand (\%) \\
\hline BW-SM-01 & 8 & 35 & 57 \\
BW-SM-02 & 8 & 30 & 62 \\
BW-SM-03 & 7 & 28 & 65 \\
BW-SM-04 & 8 & 25 & 67 \\
BW-SM-05 & 7 & 26 & 68 \\
BW-SM-06 & 7 & 30 & 63 \\
BW-SM-07 & 6 & 25 & 69 \\
BW-SM-08 & 7 & 28 & 65 \\
BW-SM-09 & 8 & 26 & 66 \\
BW-SM-10 & 6 & 27 & 67 \\
BW-SM-11 & 6 & 28 & 66 \\
BW-SM-12 & 8 & 32 & 60 \\
\hline
\end{tabular}




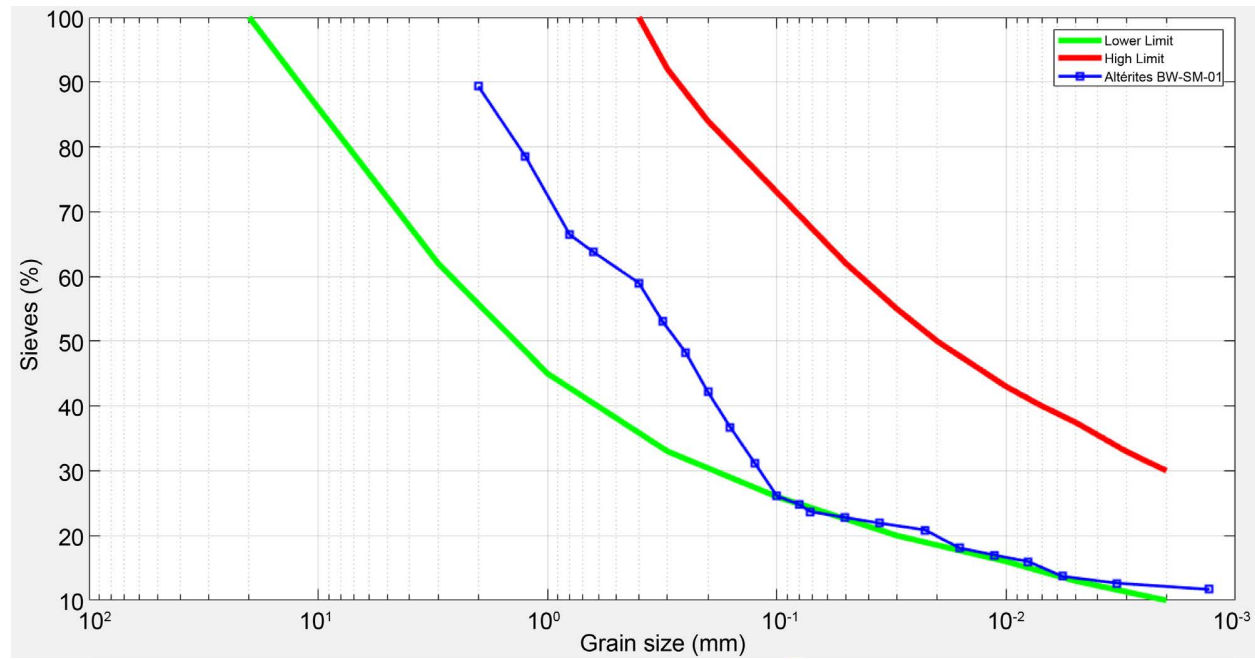

Figure 3. Grain size curve of natural material BW-SM-01.

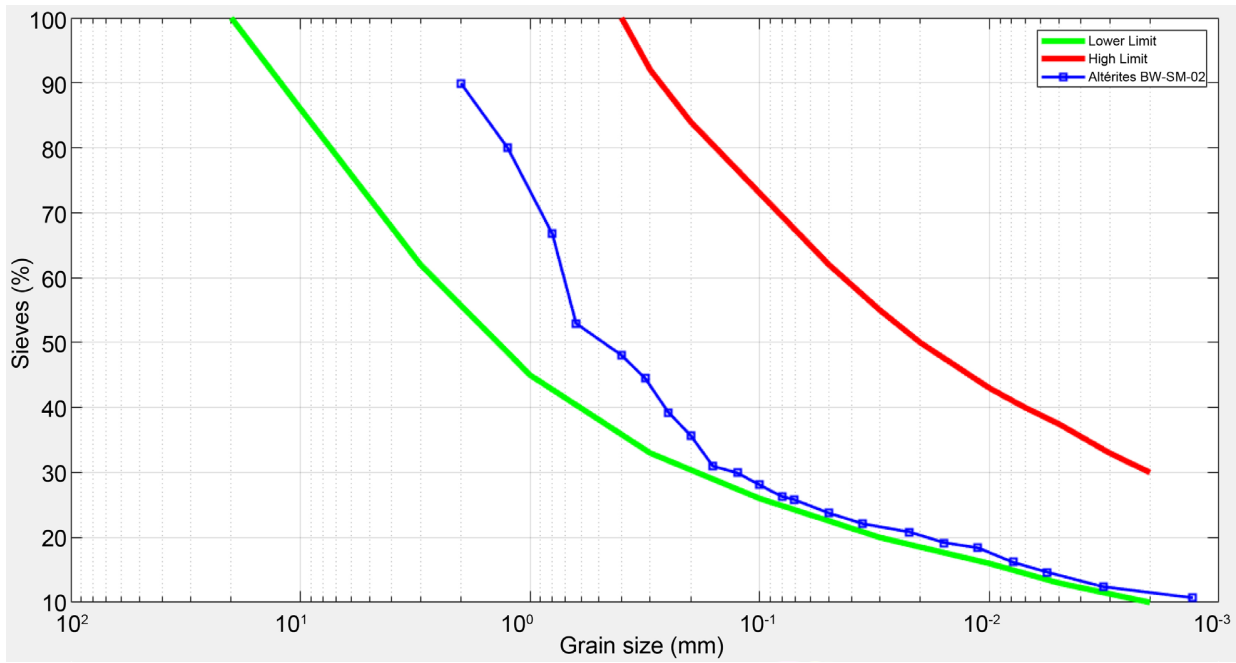

Figure 4. Grain size curve of natural material BW-SM-02.

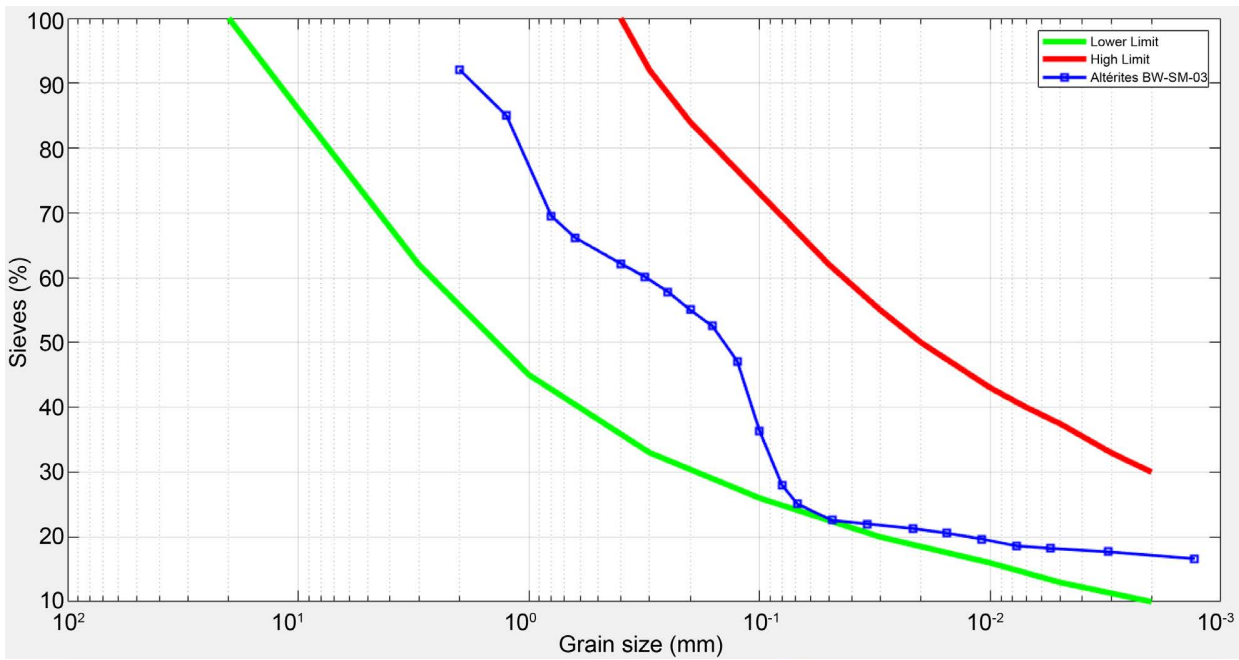

Figure 5. Grain size curve of natural material BW-SM-03. 


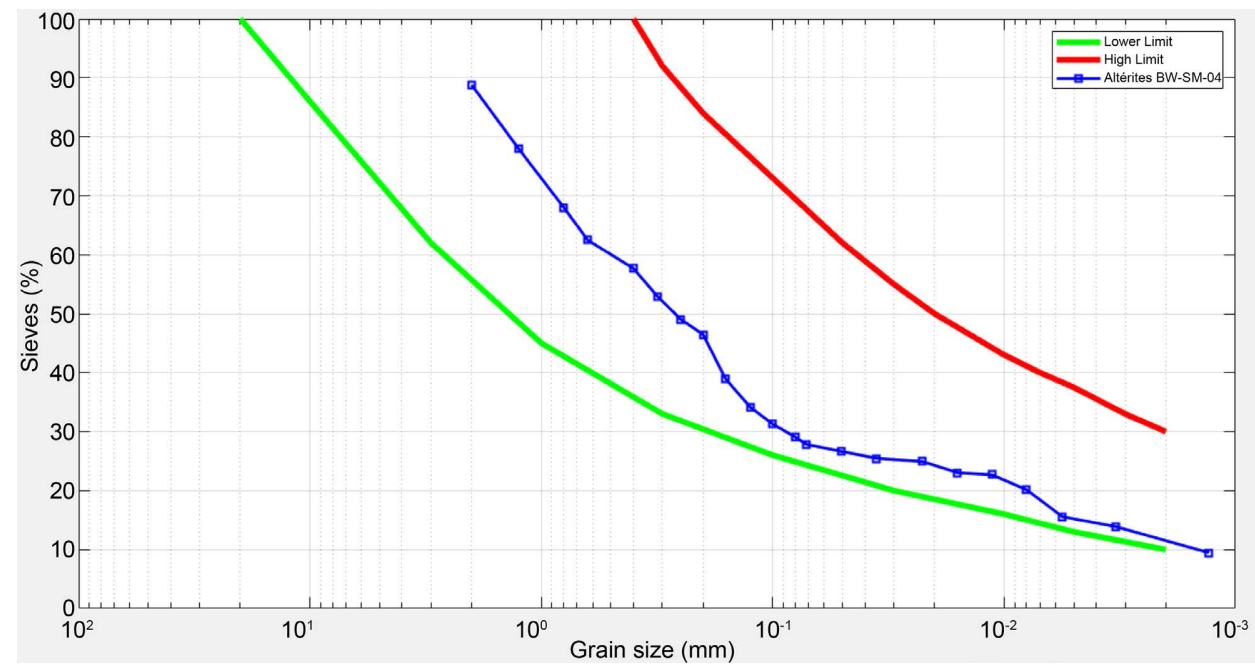

Figure 6. Grain size curve of natural material BW-SM-04.

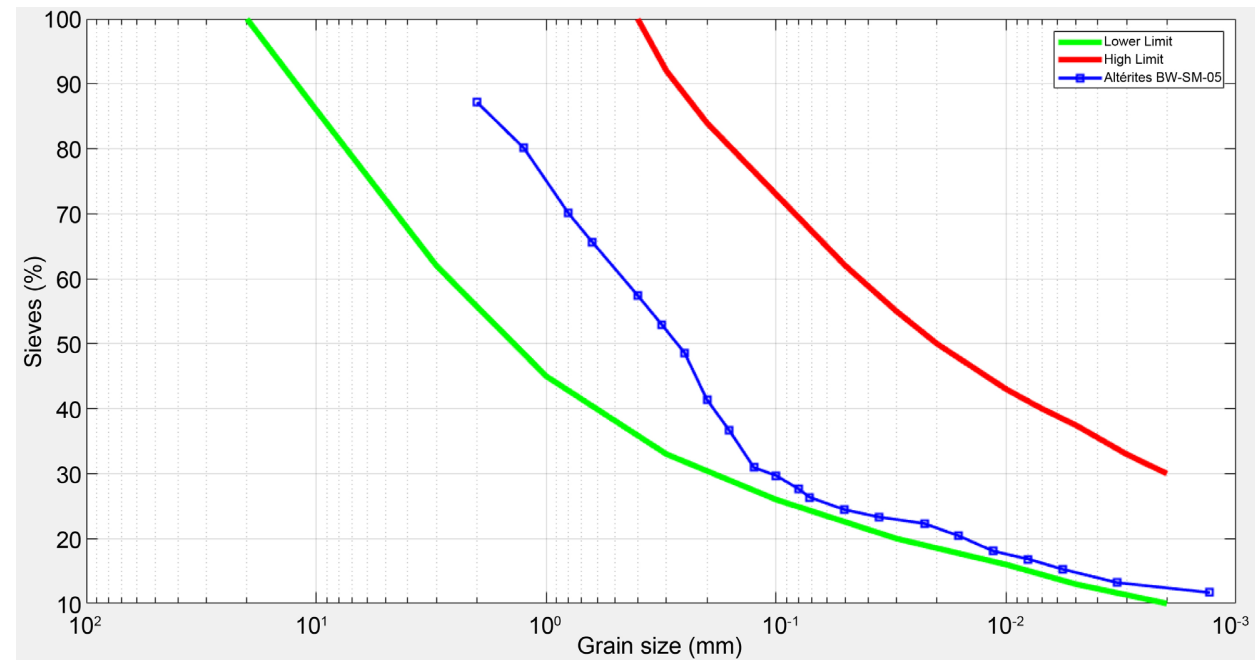

Figure 7. Grain size curve of natural material BW-SM-05.

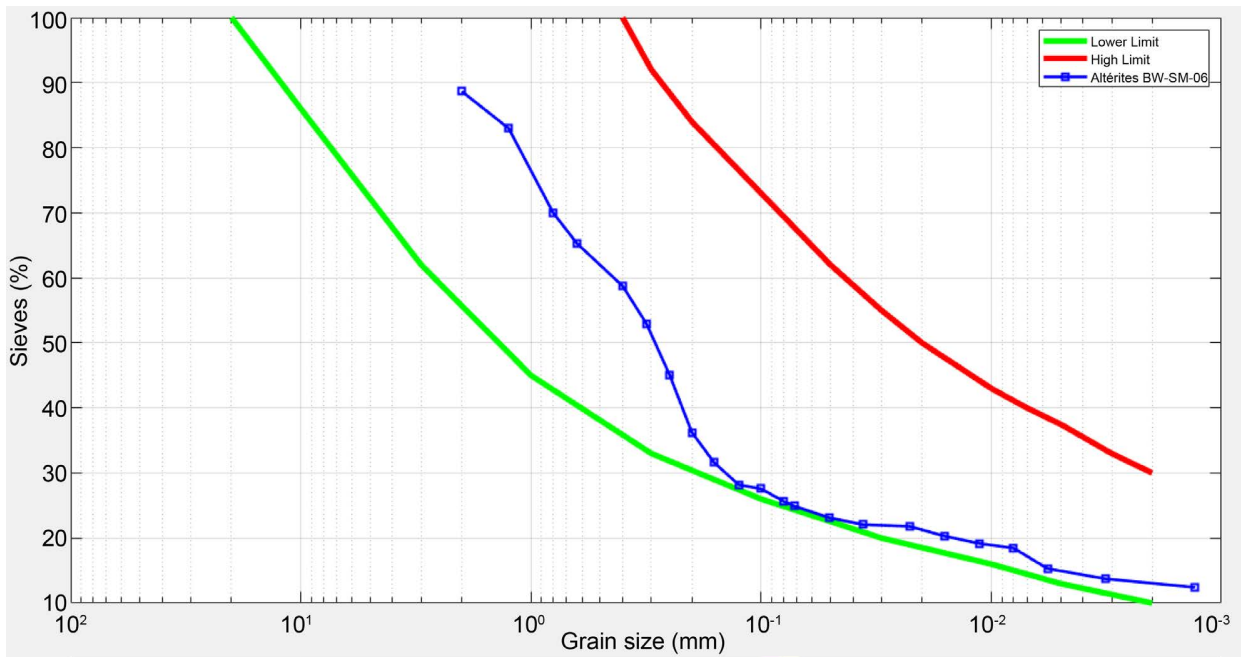

Figure 8. Grain size curve of natural material BW-SM-06. 


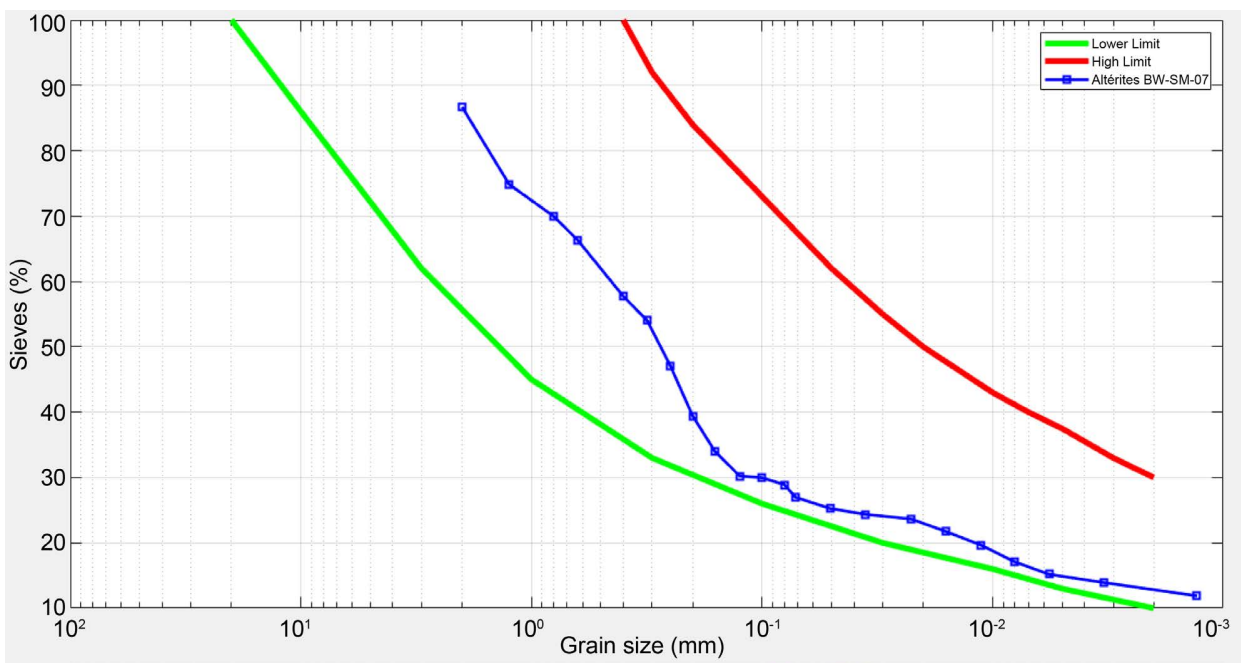

Figure 9. Grain size curve of natural material BW-SM-07.

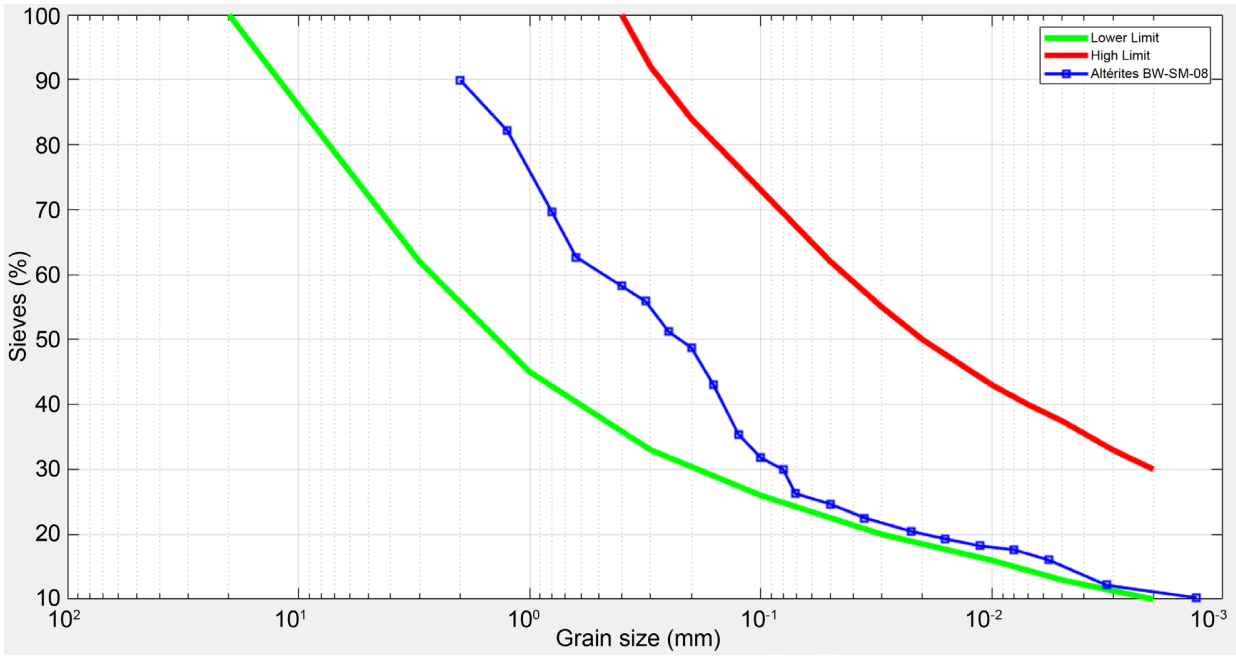

Figure 10. Grain size curve of natural material BW-SM-08.

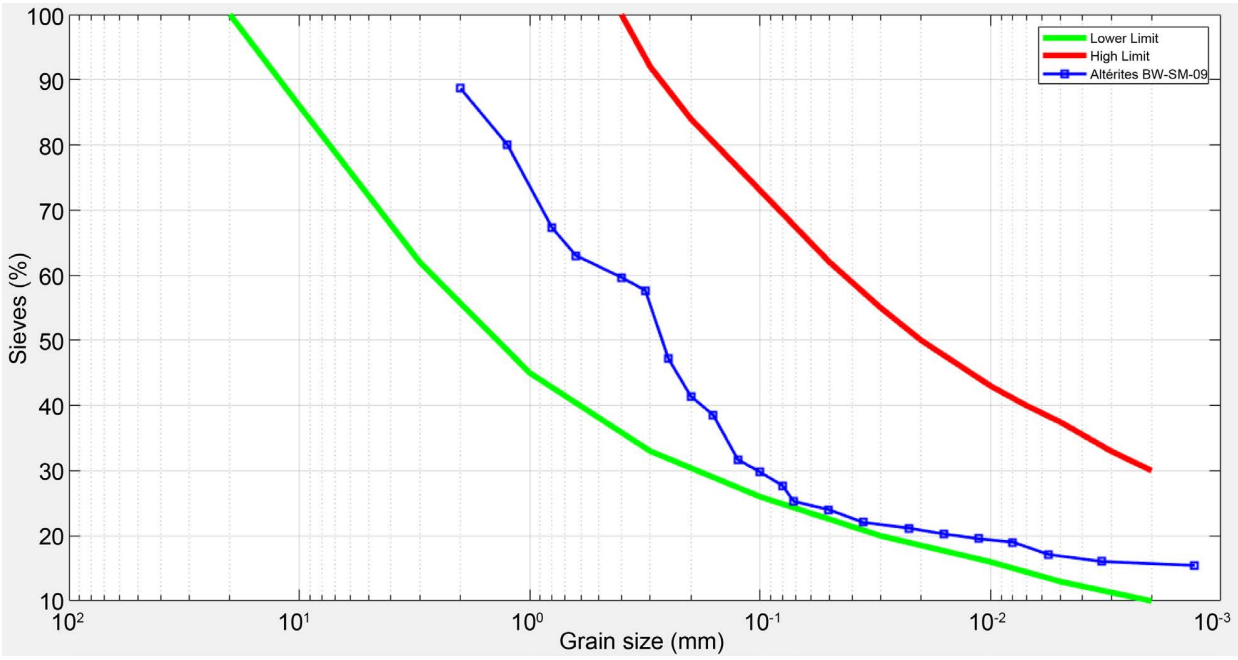

Figure 11. Grain size curve of natural material BW-SM-09. 


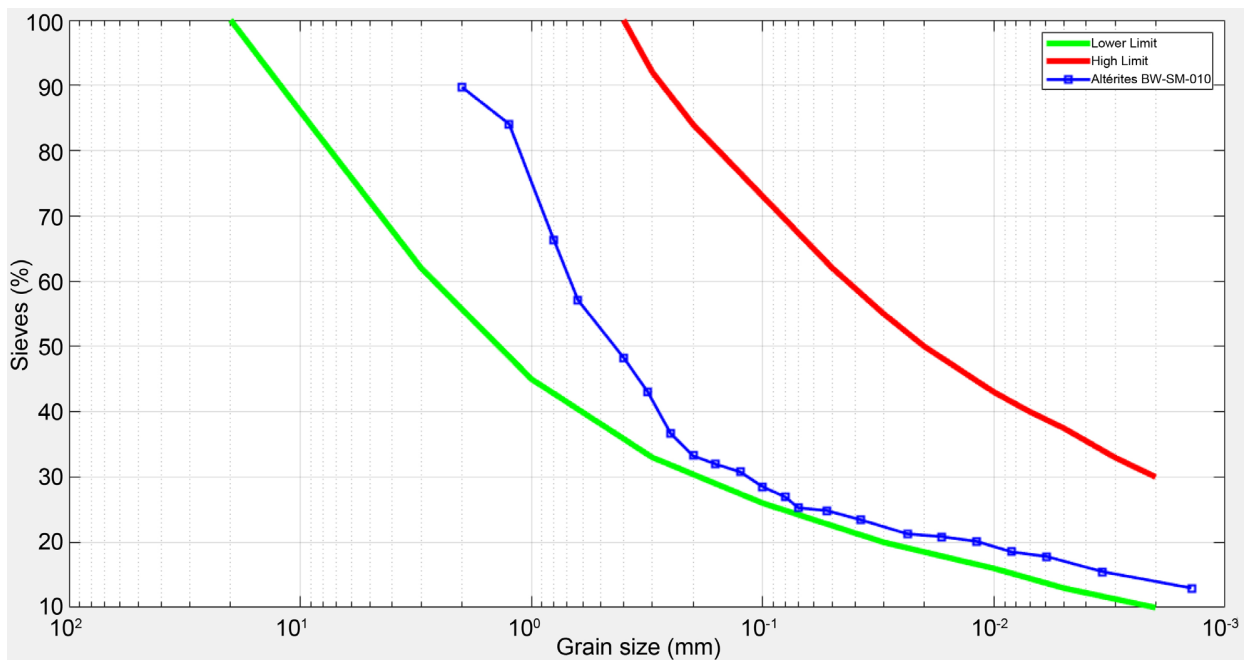

Figure 12. Grain size curve of natural material BW-SM-10.

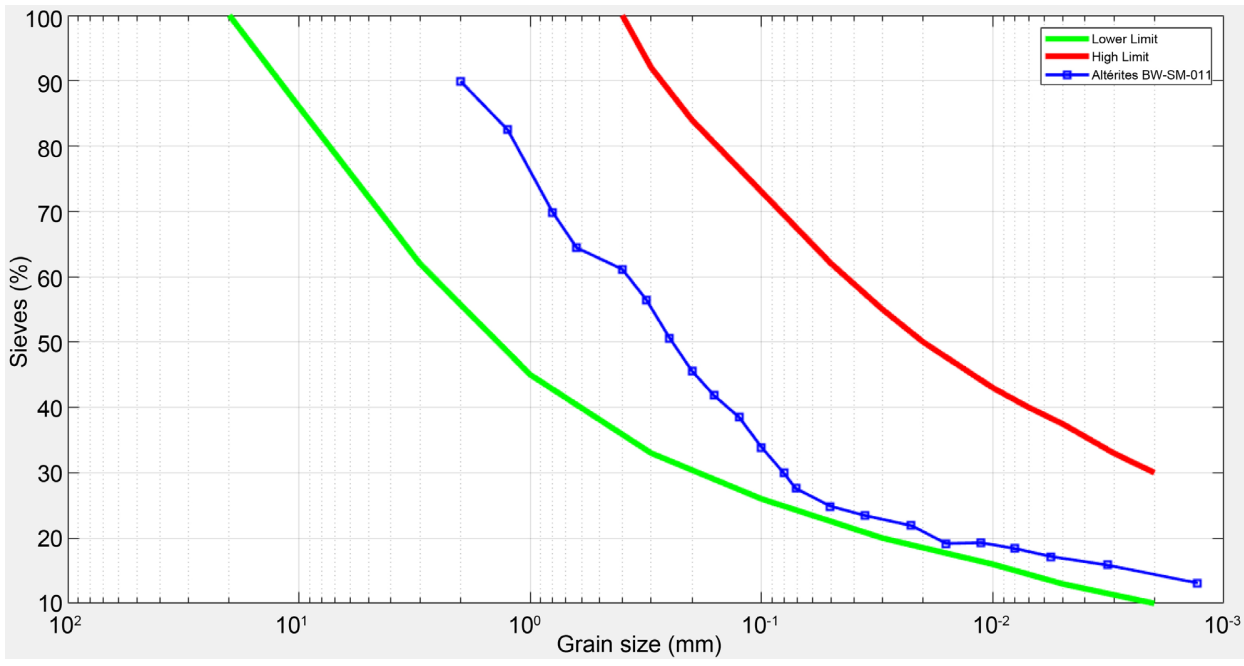

Figure 13. Grain size curve of natural material BW-SM-11.

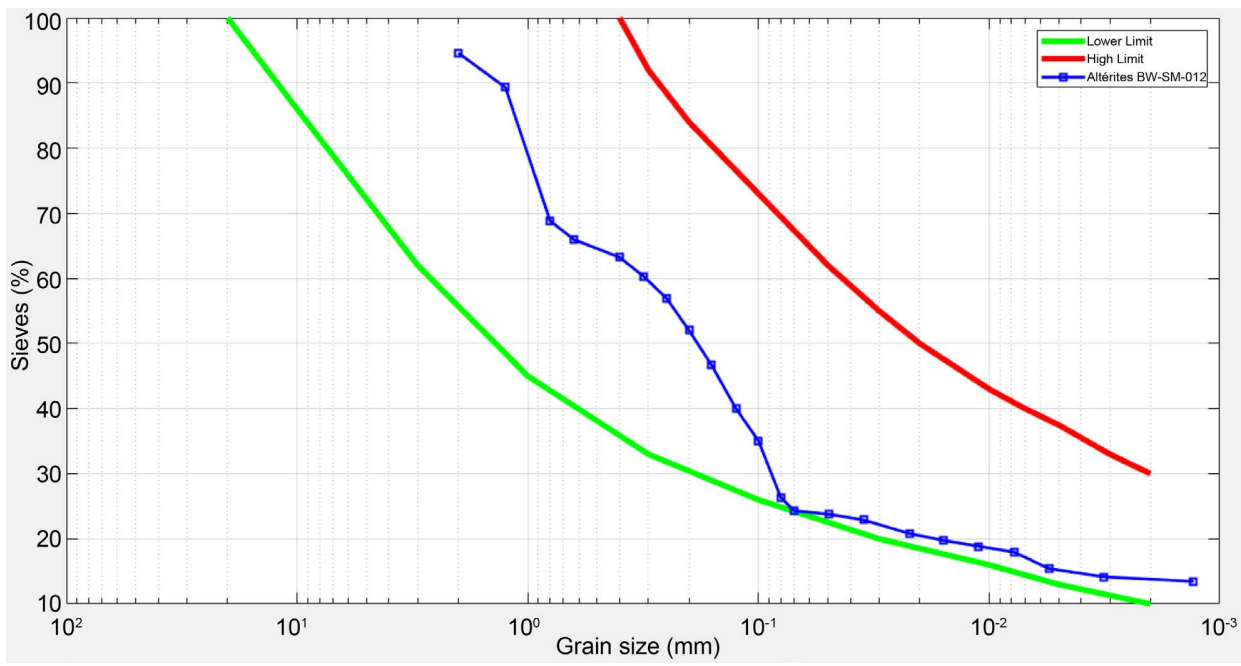

Figure 14. Grain size curve of natural material BW-SM-12. 
From this distribution, on the whole we notice that the studied materials are rich in fine particles. Their sieve size curves enter the preferential range (Appendix 2. Grain size range for soil suitable for earth construction) suggested (AFNOR XP P13-901: 2001-10) [22] for the manufacture of Compressed Earth Bricks [23] [24] [25].

\subsection{Consistency Parameters}

The consistency parameters of the studied soils are presented in Table 5 .

Table 5 shows that the plasticity index (Ip) of materials BW-SM-01 to BW-SM-12 is between 17.15 and $19.36 \%$ with an arithmetic mean of $18.25 \%$. The consistency index (Ic) is between 0.18 and 1.57 with an arithmetic mean of $1.08 \%$, which gives the materials studied a plastic character. Similarly, the liquidity index (Il) is less than zero with an arithmetic average of -0.08 , which gives these materials a character of hard plastic consistency.

The diagram on Figure 15 shows that the points of the studied material fall within the preferential plasticity range recommended by the AFNOR (2001) [22] standard for the manufacture of Compressed stabilized Earth Bricks (Appendix 3 Plasticity range indicated for soils used in earth construction).

The liquid limit $\mathrm{W}_{\mathrm{L}}$ varies from $31.9 \%$ to $40.25 \%$ with an arithmetic mean of $34.66 \%$. The plasticity limit $\mathrm{W}_{\mathrm{P}}$ ranges from $14.20 \%$ to $21.77 \%$ with arithmetic mean of $16.41 \%$. The plasticity index of the studied soils varies from $17.15 \%$ to $19.36 \%$, with an average of $18.25 \%$. These values of variation agree with the ranges that are indicated in the specification (AFNOR XP P13-901: 2001-10) [22] as indicated in Appendix 3, and in the study made by Laurent GUERIN (1985) [26] where the liquidity limit, the plasticity limit and the plasticity index to be considered must be respectively between $25 \%$ and $45 \% ; 10 \%$ and $25 \%$; and

Table 5. Consistency parameters of the samples.

\begin{tabular}{cccccc}
\hline Samples & $\mathrm{W}_{1}(\%)$ & $\mathrm{Wp}(\%)$ & $\mathrm{Ip}(\%)$ & $\mathrm{I}_{1}$ & $\mathrm{Ic}$ \\
\hline BW-SM-01 & 32.50 & 15.01 & 17.49 & -0.23 & 1.23 \\
BW-SM-02 & 36.36 & 17.83 & 18.53 & -0.30 & 1.29 \\
BW-SM-03 & 40.35 & 21.78 & 18.57 & 0.82 & 0.18 \\
BW-SM-04 & 31.90 & 13.81 & 18.08 & -0.09 & 1.09 \\
BW-SM-05 & 32.01 & 14.86 & 17.15 & -0.21 & 1.21 \\
BW-SM-06 & 33.40 & 16.08 & 17.32 & -0.09 & 1.09 \\
BW-SM-07 & 33.10 & 15.31 & 17.79 & -0.16 & 1.16 \\
BW-SM-08 & 35.20 & 16.16 & 19.04 & -0.57 & 1.57 \\
BW-SM-09 & 35.80 & 17.16 & 18.64 & -0.57 & 1.57 \\
BW-SM-10 & 32.70 & 14.40 & 18.30 & -0.08 & 1.08 \\
BW-SM-11 & 33.57 & 14.21 & 19.36 & -0.16 & 1.16 \\
BW-SM-12 & 39.10 & 20.34 & 18.76 & 0.66 & 0.35 \\
\hline
\end{tabular}




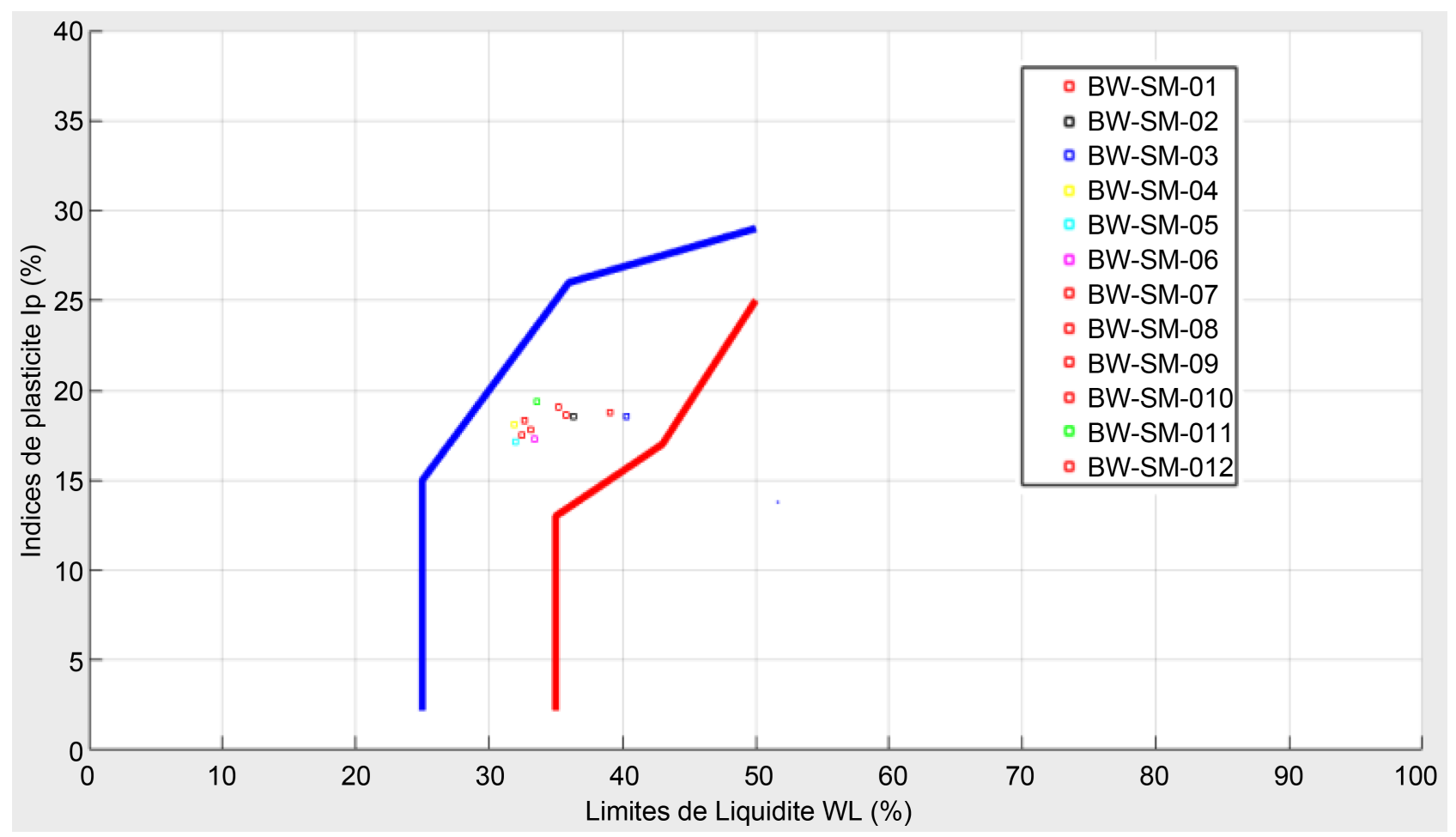

Figure 15. Position of the studied samples in the earth plasticity diagram for CSEB.

$7 \%$ and $25 \%$, related to recommended material for the manufacture of CSEB.

\subsection{Geotechnical Classification}

The quick preliminary (smell) test attested that the sample materials have a poor Organic Matter Content. The particle size curves attested that the 12 samples materials have at least $70 \%$ of particles whose size is less than 0.08 millimetres. According to the CLRB Classification System [27], those two parameters indicate that these samples materials are either Clay or Silt. The position of the studied samples in the Casagrande chart found the values of the plasticity index and the liquidity limit, show that the whole material of all the samples are classified as Ap (Plastic Clay Class).

\section{Conclusion}

The present work has shown that the studied soils are rich in fine particles. They are essentially plastic floors of class Ap of the CLRB classification system. The grain size curves of all the samples studied and the points that represent them lie within the preferential zones of good soils for the production of compressed earth blocks. It appears that in their natural state, the studied materials can be used for this purpose. The density of tropical soils can serve as an important index of their strength and durability. This is because density is mainly influenced by the types of minerals and oxides present in the soils. In order to obtain the acceptable properties for the materials for the production of stabilized earth 
blocks, the percentage of fine particles is an important parameter. But also the type of soil and the geographical position can play an important role in its properties. The methods used in the context of this article are standard and remain applicable for all similar studies.

\section{Conflicts of Interest}

The authors declare no conflicts of interest regarding the publication of this paper.

\section{References}

[1] Ait Kadi, S. (2012) Performances thermique du matériau terre pour un habitat durable des régions aride et semi arides: Cas de Timimoun. Université Mouloud Mammeri Tizi Ouzou, Algerie.

[2] Association le Gabion (2000) Document terre La brique de terre comprimée. 05200 EMBRUN.

[3] Morel, J.C., Mesbah, A., Oggero, M. and Walker, P. (2001) Building Houses with Local Materials: Means to Drastically Reduce the Environmental Impact of Construction. Building and Environment, 36, 1119-1126. https://doi.org/10.1016/S0360-1323(00)00054-8

[4] Jimenez Delgado, M.C. and Guerrero, I.C. (2007) The Selection of Soils for Unstabilised Earth Building: A Normative Review. Construction and Building Materials, 21, 237-251. https://doi.org/10.1016/j.conbuildmat.2005.08.006

[5] Bachar, M., Azzouz, L., Rabehi, M. and Mezghiche, B. (2014) Characterization of a Stabilized Earth Concrete and the Effect of Incorporation of Aggregates of Cork on Its Thermo-Mechanical Properties: Experimental Study and Modeling. Construction and Building Materials, 74, 259-267.

https://doi.org/10.1016/j.conbuildmat.2014.09.106

[6] Oyelami, C.A. and Van Rooy, J.L. (2016) A Review of the Use of Lateritic Soils in the Construction/Development of Sustainable Housing in Africa: A Geological Perspective. Journal of African Earth Sciences, 119, 226-237. https://doi.org/10.1016/j.jafrearsci.2016.03.018

[7] Arumala, J.O. (2007) Compressed Earth Building Bricks for Affordable Housing. The Construction and Building Research Conference of the Royal Institution of Chartered Surveyors, London, 2007, 21.

[8] Oti, J.E., Kinuthia, J.M. and Bai, J. (2009) Engineering Properties of Unfired Clay Masonry Bricks. Engineering Geology, 107, 130-139. https://doi.org/10.1016/j.enggeo.2009.05.002

[9] Das, S.K., Samui, P. and Sabat, A.K. (2010) Application of Artificial Intelligence to Maximum Dry Density and Unconfined Compressive Strength of Cement Stabilized Soil. Geotechnical and Geological Engineering, 29, 329-342. https://doi.org/10.1007/s10706-010-9379-4

[10] Deboucha, S. and Hashim, R. (2011) Correlation between Total Water Absorption and Wet Compressive Strength of Compressed Stabilised Peat Bricks.

[11] Villamizar, M.C.N., Araque, V.S., Reyes, C.A.R. and Silva, R.S. (2012) Effect of the Addition of Coal-Ash and Cassava Peels on the Engineering Properties of Compressed Earth Blocks. Construction and Building Materials, 36, 276-286.

https://doi.org/10.1016/j.conbuildmat.2012.04.056 
[12] Houben, H. and Guillaud, H. (1994) Earth Construction-A Comprehensive Guide. Intermediate Technology, London.

[13] Taallah, B., Guettala, A., Guettala, S. and Kriker, A. (2014) Mechanical Properties and Hygroscopicity Behavior of Compressed Earth Block Filled by Date Palm Fibers. Construction and Building Materials, 59, 161-168. https://doi.org/10.1016/j.conbuildmat.2014.02.058

[14] Margesin, R. and Schinner, F. (2005) Manual of Soil Analysis. Monitoring and Assessing Soil Bioremediation. Springer, Berlin, 370 p. https://doi.org/10.1007/3-540-28904-6

[15] Norme XP CEN ISO/TS 17892-1 (2005) Reconnaissance et Essais géotechniquesEssais de Laboratoire sur les sols-Partie 1: Détermination de la teneur en eau.

[16] Norme NF P 94-054 (1991) Sols: Reconnaissance et essais. Détermination de la masse volumique des sols fins en laboratoire. Méthode du pycnomètre à eau. AFNOR, Paris.

[17] Norme NF P 94-053 (1991) Sols: Reconnaissance et essais. Détermination de la masse volumique des sols fins en laboratoire. Méthode de la trousse coupante, du moule et de l'immersion dans l'eau. AFNOR, Paris.

[18] Norme NF P 18-560 (1990) Sols: Reconnaissance et essais, Analyse granulométrique par tamisage. AFNOR, Paris.

[19] Norme NF P 94-057 (1992) Sols: Reconnaissance et essais, Analyse granulométrique des sols-Méthode par sédimentométrie. AFNOR, Paris.

[20] Norme NF P 94-051 (1993) Sols: Reconnaissance et essais. Détermination des limites d'Atterberg. Limite de liquidité à la coupelle-limite de plasticité au rouleau. AFNOR, Paris.

[21] Norme ISO 13317-1 (2001) Détermination de la distribution granulométrique par les méthodes de sédimentation par gravité dans un liquide-Partie 1: Principes généraux et lignes directrices. AFNOR, Paris.

[22] Norme AFNOR XP P13-901:2001-10 (2001) Grain Size Range and Plasticity Range for Suitable Soil in Earth Construction.

[23] Rigassi, V. (1995) Compressed Earth Blocks: A Publication of Deutsches Zentrum fur Entwicklungstechnologien-GATE, a Division of the Deutsche Gesellschaft fur Technische Zusammenarbeit (GTZ) GmbH in Coordination with the Building Advisory Service and Information Network. Vieweg, Braunschweig.

[24] Delgado, M.C.J. and Guerrero, I.C. (2006) Earth Building in Spain. Construction and Building Materials, 20, 679-690.

https://doi.org/10.1016/j.conbuildmat.2005.02.006

[25] Goodary, R., Lecomte-Nana, G.L., Petit, C. and Smith, D.S. (2012) Investigation of the Strength Development in Cement-Stabilised Soils of Volcanic Origin. Construction and Building Materials, 28, 592-598. https://doi.org/10.1016/j.conbuildmat.2011.08.054

[26] Guerin, L. (1985) Construction à faible coût dans les programmes spéciaux de travaux publics.

[27] Classification des sols fins selon le laboratoire central des ponts et chausses (LCPC) à Paris. 


\section{Appendices}

Appendix 1: MATLAB code applied to the particle size curve of the sample BW-

SM-01

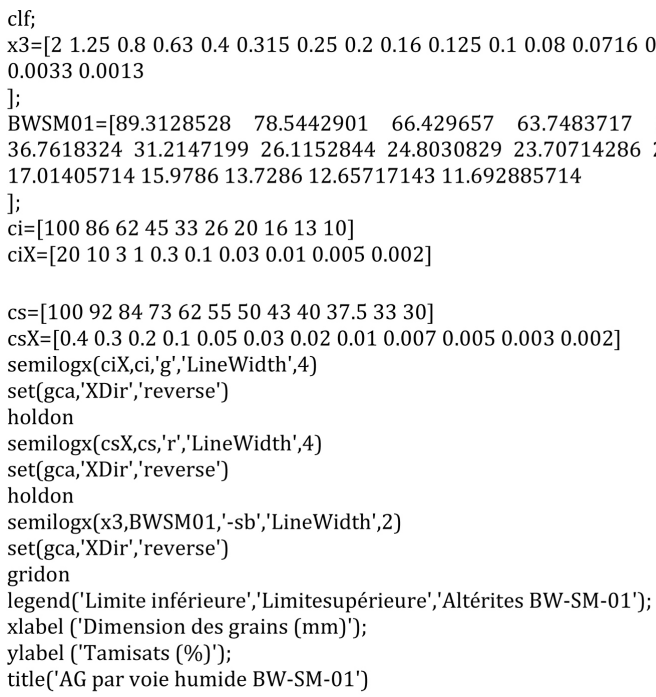

Appendix 2: Grain size range for suitable soil in earth construction (AFNOR XP P13-901:2001-10)

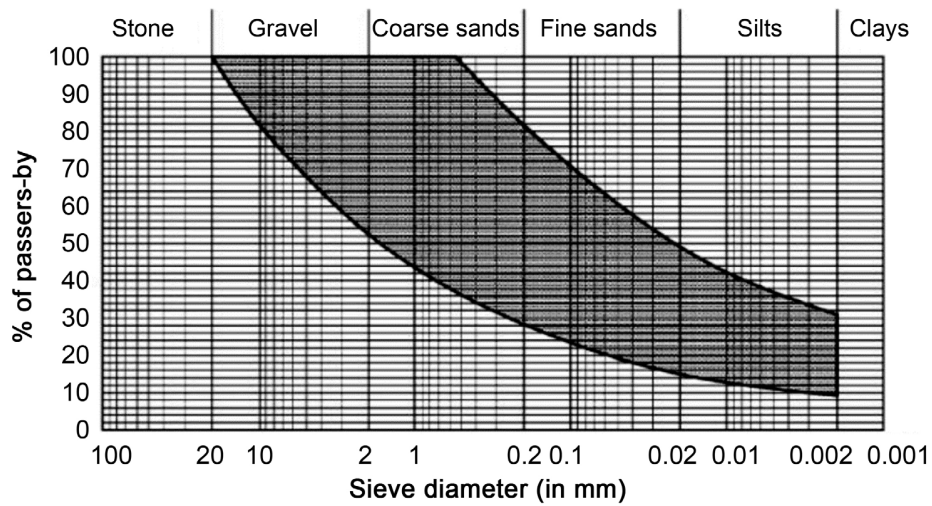

Appendix 3: Plasticity range indicated for soils used in earth construction (AFNOR XP P13-901:2001-10)

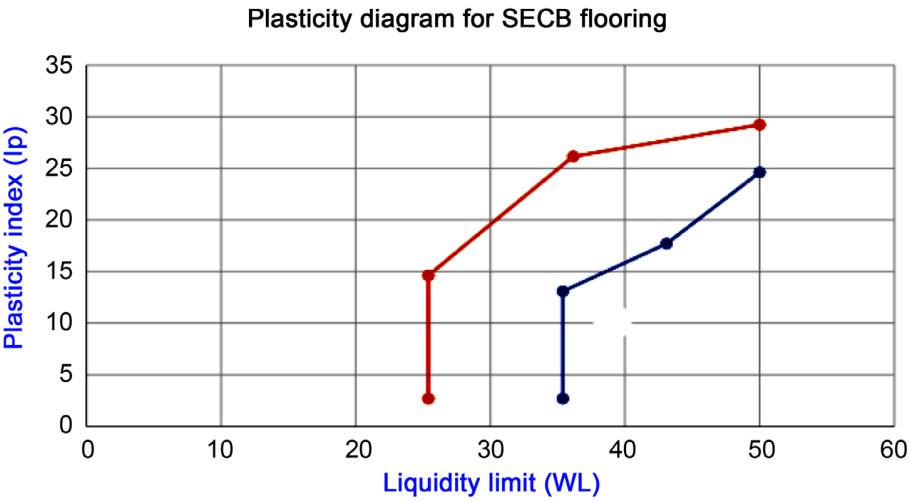

